\title{
Open Defecation Profile of Rural Communities in Cross River and Akwa Ibom States of the Niger Delta, Nigeria
}

\author{
RandymayEja Kalu ${ }^{1}$, Kimboline Donatus Etim², \\ Okon Aniekanabasi Jonathan ${ }^{2}$ and Matthew Egbobor Eja ${ }^{2 *}$ \\ ${ }^{1}$ Federal Medical Centre, Yenogoa, Bayelsa, Nigeria \\ ${ }^{2}$ Department of Public Health, University of Calabar,Cross River State, Nigeria \\ *Corresponding author
}

\section{Keywords}

Open defecation,

Households,

Sanitation facilities,

Rural communities,

Niger Delta

\section{Article Info}

Accepted:

17 November 2019

Available Online:

10 December 2019

\section{A B S T R A C T}

Open defecation is a global practice, the prevalence of which differs from country to country, and from region to region. The prevalence is particularly significant in subSaharan Africa and Asia. The aim of this study was to examine the open defecation profile of rural communities of Cross River and Akwalbom States in the Niger Delta region of Nigeria, focusing on the level of sanitation of the two states. A cross-sectional study was adopted, employing a multi-stage random sampling using questionnaires which were distributed to sampled households in the two states. The result revealed a high significant difference $(\mathrm{P}<0.01)$ between rural Cross River and Akwalbom States with respect to availability of sanitation facilities. 190(90.48\%) and 98(46.67\%) respondents in Cross River and Akwalbom States respectively, owned faecal facilities including 17(9.91\%) and 25(21.51\%) respondents in Cross River and Akwalbom States owning water closet connected to septic system, respectively. Also, 105(56.15\%) respondents in Cross River State and 39(39.80\%) in Akwalbom State owned simple pit latrines, while 20(9.52\%) and 112(52.33\%) respondents in Cross River and Akwalbom States, respectively, did not own faecal disposal facilities, indicating open defecation as alternative. Respondents with improved sanitation coverage in Cross River and Akwalbom States were 61.90\% and $38.10 \%$ respectively, while unimproved sanitation respondents recorded $31.43 \%$ and $68.57 \%$ respectively, indicating that sanitation and coverage are worse in Akwalbom State. This study identifies absence of sanitation facilities as a big factor influencing open defecation in rural Cross River State communities and rural coastal communities in Akwalbom State.

\section{Introduction}

According to Abubakar (2018) reporting progress on sanitation and drinking water 2015 update by UNICEF/WHO (2015), open defecation (OD) is a kind of sanitation which involves the disposal of human waste in garbage bins, water bodies, public areas, forests, farmlands or other open and green spaces. According to Saleem, Burdett \& 
Heaslip (2019), open defecation is the practice of defecating in open fields, waterways and open trenches without any proper disposal of human excreta. WHO/UNICEF (2017), in their report on progress on drinking water and sanitation - 2017 update, further classified open defecation as unimproved sanitation.

Open defecation is practised in many countries, and sometimes as a culture or tradition (Cookey et al., 2008; Coffey et al., 2014). Open defecation is prevalent mostly in sub-Saharan Africa and Asia. It has been reported that $90 \%$ of people who practise open defecation reside in rural areas of three regions, i.e., sub-Saharan Africa, Central Asia and Southern Asia (WHO/UNICEF, 2017; Saleem et al., 2019). At least $25.1 \%$ or 46 million people in Nigeria practising open defecation in 2015, placed Nigeria in the third position in the world in open defecation prevalence after India and China (Abubakar, 2018). Coffey et al., (2014) report that most people who live in India defecate in the open, and most people worldwide who defecate in the open live in India. It has also been reported that $67 \%$ of rural households and $13 \%$ of urban households in India defecate in the open (Coffey et al., 2014), while India accounts for $60 \%$ of the world's open defecation (WHO \& UNICEF, 2014).

Open defecation is practised in all the regions of Nigeria (North, South, East and West). Unlike a previous report that Nigeria was third after India and China in 2015 (Abubakar, 2018), Nigeria is reported to rank second among countries practising open defecation globally, leading to social, economic and health implications (NewsBank Inc., 2019). After India, Nigeria is reported to be the alternate headquarters for open defecation with over 47 million persons still engaging in the act across the country (NewsBank Inc., 2019). Infact, NewsBank Inc. (2018) reports that Nigeria in the past 15 years has remained among the top five countries practicing open defecation. The highlight of the percentage of population practicing open defecation across the six geo-political zones of Nigeria shows North-Central 53.9\%, South-east 22.4\%, North-east $21.8 \%$, South-south $17.9 \%$, Southwest $28.0 \%$ and North-west $10.3 \%$ (NewsBank Inc., 2019), indicating that open defecation is practiced in all regions of Nigeria. According to Water, Sanitation and Hygiene (WASH) Normal Outcome Routine Mapping (NORM), as reported by NewsBank Inc. (2019), one in four Nigerians defecates in the open, while one in two persons in the North-Central defecates in the open; also, out of the 47 million practicing open defecation in Nigeria, 16 million are from the NorthCentral.

Most communities in the Niger Delta reside in the sea coasts, estuaries and mangrove swamps, and generally, there is absence of sanitation facilities (Cookey et al., 2008). This implies that coastal communities defecate into the surface water as a culture. Some communities that live far from the coast defecate on bare ground in bushes, dark corners and even rivers that pass through their communities. A good percentage of people in the Niger Delta do not have access to sanitation facilities such as faecal disposal facilities, water closet connected to septic system, ventilation improved toilet, simple pit toilet and even waste bin for children (Okon, 2017).

The implication of open defecation is water and food pollution by faecal material through run-off input into drinking water sources, and pests and rodents which transfer diseasecausing organisms into food. These diseasecausing organisms are associated with diarrhoea, typhoid fever, cholera, giardiasis, infantile papalysis (poliomyelitis), etc. (Eja, 2003). Thus, open defecation poses a significant threat to the environment and 
human health, safety and dignity, especially for women, girls and children (Desai et al., 2015; Abubakar, 2018). Besides, the practice of open defecation has an economic, social and health impact on national development. For instance, Nigeria loses about N455 billions of her GDP annually to poor sanitation and a third of that cost to open defecation (NewsBank Inc., 2019).

To eliminate the scourge of open defecation, several affected governments, other stakeholders and WHO/UNICEF (Desai et al., 2015; UNICEF/WHO, 2015) have initiated some interventions, especially as health, dignity and privacy for women and children are human rights (Abubakar, 2018) owing to the failure of Millennium Development Goals (MDGs) which was targeted at improved sanitation that was not met after 15 years, resulting in 2.5 billion people not having access to improved sanitation. It was again highlighted as a key issue in the Sustainable Development Goals (SDGs) focusing more on water and sanitation for all, especially women and girls (Abubakar, 2018). There are other forms of interventions to eliminate open defecation which focus on sensitization and provision of latrines for rural communities but end only in some percent successful. For instance, in 2014, Indian government initiated the SWACHH BHARAT MISSION (SBM) to eliminate open defecation by 2019 , focusing on increase in the number of households that have latrines and increase in the number of household members using latrines, besides subsidizing building latrines at $80 \%$ for those who wanted to build latrines (O' Reilly et al., 2017). Even then, a good number of the rural populations still practise open defecation with $67 \%$ of rural households and $13 \%$ of urban households defecating in the open (Coffey et al., 2014). In Nigeria, a national roadmap to eliminate open defecation in 2025 at national level as well as Water Supply and Sanitation Agency (RUWASA) was set up (Abubakar,
2018) to help recognize the adverse effects of poor sanitation and open defecation, and design a programme to become open defecation free. Up till now, these intervention initiatives have not yielded full results.

However, there are several factors associated with open defecation in the communities, especially rural communities of those countries where open defecation is practised. Such factors may be availability of sanitation facilities, demographic (Abubakar, 2018; NewsBank, 2019), remoteness (O' Reilly et al., 2017), socio-cultural and behavioural attitude (Coffey et al., 2014). The aim of this study was to examine the open defecation profile of rural communities in the Niger Delta region of Nigeria, focusing on sanitation facilities available in the study areas as determinants of open defecation.

\section{Materials and Methods}

\section{Study areas}

The study areas are Akwalbom and Cross River States, located at South-Southern part of Nigeria and known as the Niger Delta. AkwaIbom State lies between latitudes $4^{\circ} 231^{\prime}$ and $5^{\circ} 331^{\prime}$ North, and longitudes $7^{\circ} 251^{\prime}$ and $8^{\circ} 251^{\prime}$ 'East; it is bounded on the West by Rivers State, the East by Cross River State, the North by Abia State and the South by the Gulf of Guinea (Okon, 2017). The coastal area of the state consists of mangrove and swamp forests, while the Northern and Eastern parts consist of tropical rainforest and mangrove forest. Akwalbom State covers a total land area of $7,249 \mathrm{~km}^{2}$ and a 2013 projected population of 4,931,091 with an average population density of $680 / \mathrm{km}^{2}$ (Directorate of Statistics, 2013). The projected rural population is $3,944,816$, while urban population is 986,275 (Directorate of Statistics, 2006). On the other hand, Cross River State lies between latitudes $5^{\circ} 20^{\prime}$ and 
$6^{\circ} 20^{\prime}$ North and longitudes $8^{\circ} 05^{\prime}$ and $8^{\circ} 45^{\prime}$ East (Eja, 2006). It is bounded on the East by the Republic of Cameroon, the North by Benue and Ebonyi States, the West by Akwalbom State and the South by the Gulf of Guinea.

The state consists of mangrove forest in the South, swamp forest, tropical high forest (THF) and derived savannah woodland in the North (Eja, 2006). Cross River State covers a total land area of $22,341 \mathrm{~km}^{2}$ and a 2013 projected population of 3,606,654 which translated to an average population density of $161 / \mathrm{km}^{2}$ in 2013 (Cross River Bureau of Statistics, 2006). An estimated rural population of Cross River State is more than two third of the population of Cross River State. Cross River and Akwalbom States are shown in Figure 1.

\section{Study design}

A cross-sectional study was adopted. A multistage sampling was employed during the study. The sampling was done in three stages. First, six Local Government Areas (LGAs) (3 from Akwalbom State and 3 from Cross River State) were randomly selected from Cross River State and Akwalbom States. A list consisting of the names of Cross River State and Akwalbom State LGAs was used as sample frame. Secondly, two villages each were randomly selected from the selected LGAs making a total of 12 villages which were used as sample frames. In Nigeria today, rural areas are assumed to have a population of 20,000 per community (NPC, 2007).

The last stage was a systematic random selection of 35 households from each of the selected villages for questionnaire administration. The LGAs selected in Akwalbom State were Oron, Mbo and IkotAbasi. The LGAs selected from Cross River State were Bekwarra, Ikom and
Akamkpa. The study population was made up of household heads or adult members of each household. The specific sampling location in the two states is indicated in Figure 1.

Two-way analysis of variance (ANOVA) was used to determine differences in means of percentages of the available sanitation facilities of the two states using the Statistical Package for Social Sciences (SPSS) Version 20.

\section{Sample size determination}

The study population was determined using the statistical formula given by Lutz (1982):

$\mathrm{n}=\mathrm{z}^{2}(\mathrm{pq}) / \mathrm{d}^{2}$

where:

$\mathrm{n}=$ minimal sample size

$\mathrm{z}=$ confidence limit $=1.96$

$\mathrm{p}=$ estimated rural population with access to improved sanitation

$=0.47$

$\mathrm{Q}=1-\mathrm{p}(1-0.47)=0.53$

$\mathrm{D}=$ precision $=0.05$

$\mathrm{n}=\frac{1.96^{2} \times 0.47 \times 0.53}{0.05^{2}}$

$\mathrm{N}=\mathbf{3 8 2 . 8}$

Considering an attrition rate of $5 \%$, i.e., $382.8 / 95=402$. To attain the required sample size, 35 households each were selected from 12 villages drawn from 3 Cross River State and 3 Akwalbom LGAs respectively. A study population of 420 respondents was obtained. That means that each state will have 210 respondents. 


\section{Instrument data collection and analysis}

The data for this research were collected using questionnaires, the questions of which were related to sanitation indices. Two questionnaires were developed. One was for the researchers' observation of available sanitation facilities and the other for the respondents. The questionnaire developed for household heads or adult members of household comprised two sections. The first section constituted close-ended questions on personal data of respondents, while the second section constituted questions on households' sanitation facilities. As the questionnaires were administered to the respondents, the questions were read out to the respondents and their responses were ticked. All the questionnaires administered were retrieved.

The retrieved questionnaires were analysed for faecal disposal facilities such as availability of faecal disposal facility, type of sanitation facility, alternative faecal disposal method, disposal of children's faeces and disposal of animal faeces.

\section{Results and Discussion}

A summary of sanitation facilities in the study areas is shown in Table 1. With respect to availability of faecal disposal facilities, the table shows that Cross River State and Akwalbom State possessed 190(90.48\%) and 98(46.67\%) faecal disposal facilities, respectively. Also, respondents in the two states possessed 17(9.091\%) and 25(21.51\%) with water closet connected to septic system, respectively, while $105(56.15 \%)$ and $39(38.80 \%)$ respondents respectively had pit latrines with cover. The rest neither had available sanitation facilities nor simple pit latrines with cover. Equally, Cross River State had no pour flush latrine and ventilated improved pit latrine. However, Akwalbom State only had 2(7.64\%) respondents with pour flush latrine.
From the foregoing, there is an indication that about $9.52 \%$ of rural communities in Cross River State, and $53.33 \%$ of rural coastal communities in Akwalbom State had the alternative of open defecation. Already (Table 1) $26.79 \%$ rural coastal communities of Akwalbom State had the alternative of defecating into open water bodies. As shown in Table 1, the other alternatives opened to Cross River and Akwalbom States were defecating in bush swamp $(86.96 \%$ and $57.14 \%$ respondents), respectively. Other alternative was burying of faeces in pits, $(13.04 \%$ and $16.07 \%)$ respectively. From the scenario, children and animals in the rural communities had no opportunities of better sanitation.

Table 2 shows the sanitation coverage of the study areas. According to WHO/UNICEF (2006), coverage is the proportion of people using improved sanitation facilities such as sewer connection, septic system connection, pour flush latrine, simple pit latrine with slab, ventilated improved pit latrine and composting toilet. Sanitation coverage affected only $58.10 \%$ and $31.43 \%$ respondents in Cross River and Akwalbom States respectively, indicating that sanitation and coverage are worse in rural communities of Akwalbom State (Okon et al., 2017).

Evidently, this study shows that absence of sanitation facilities is a big factor for open defecation. Some studies have proved that absence of sanitation facilities among other factors, influences open defecation in many rural communities of developing countries (Coffey et al., 2014; O' Reilly et al., 2016). O'Connell (2014) researching on factors influencing open defecation and latrine ownership, adopted sanitation behaviour, among other factors, as a factor influencing open defecation. O'Connell (2014) identifies access to and availability of functioning latrine, sanitation products and services, 
among others, as factors influencing open defecation in rural communities. Absence of these sanitation facilities leads to shame and embarrassment associated with open defecation (O'Connell, 2014). This agrees with the result of this study which identifies absence of sanitation facilities as factors influencing open defecation, and the use of availability of sanitation facilities to examine the open defecation profile of rural communities in the Niger Delta region.

Table.1 Summary of sanitation facilities in study areas

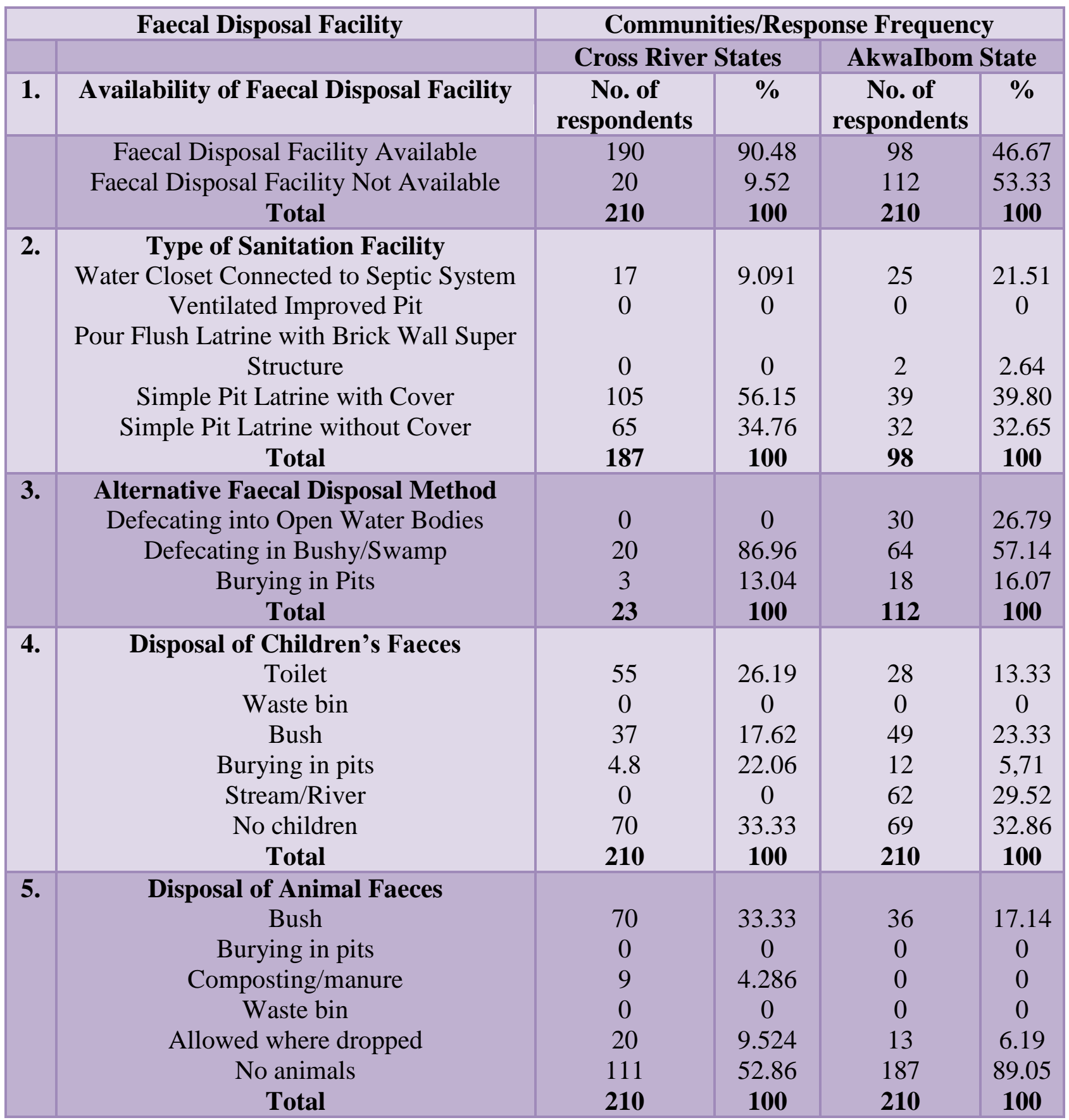

Source: Akwalbom Data (Okon, 2017). 
Table.2 Sanitation coverage in study areas

\begin{tabular}{|c|c|c|c|c|c|}
\hline \multicolumn{3}{|c|}{$\begin{array}{l}\text { Improved Sanitation Facility } \\
\quad(\text { Sample size }=210)\end{array}$} & \multicolumn{3}{|c|}{$\begin{array}{l}\text { Unimproved Sanitation Facility } \\
\quad(\text { Sample size }=210)\end{array}$} \\
\hline Facility Type & \multicolumn{2}{|c|}{$\begin{array}{cr}\text { Cross River AkwaIbom } \\
\text { State }\end{array}$} & Facility Type & $\begin{array}{c}\text { Cross River } \\
\text { State }\end{array}$ & $\begin{array}{c}\text { AkwaIbom } \\
\text { State }\end{array}$ \\
\hline $\begin{array}{c}\text { Water Closet } \\
\text { Connected to Septic } \\
\text { System }\end{array}$ & 17 & 25 & $\begin{array}{c}\text { Simple Pit } \\
\text { Latrine without } \\
\text { Cover }\end{array}$ & 65 & 32 \\
\hline $\begin{array}{l}\text { Pour Flush Latrine } \\
\text { with Brick Wall } \\
\text { Super Structure }\end{array}$ & 0 & 2 & $\begin{array}{l}\text { Defecating into } \\
\text { Open Water } \\
\text { Bodies }\end{array}$ & 0 & 30 \\
\hline \multirow[t]{2}{*}{$\begin{array}{l}\text { Simple Pit Latrine } \\
\text { with Cover }\end{array}$} & 105 & 39 & $\begin{array}{l}\text { Defecating in } \\
\text { Bush/Swamp }\end{array}$ & 20 & 64 \\
\hline & & & Burying in Pits & 3 & 18 \\
\hline Total & 122 & 66 & & 88 & 144 \\
\hline Percentage (\%) & 58.10 & 31.43 & & 41.90 & 68.57 \\
\hline
\end{tabular}

Source: AkwaIbom Data (Okon, 2017). Numbers indicate numbers of respondents.

Fig.1 Nigerian States and six geo-political regions (Abubakar, 2017)

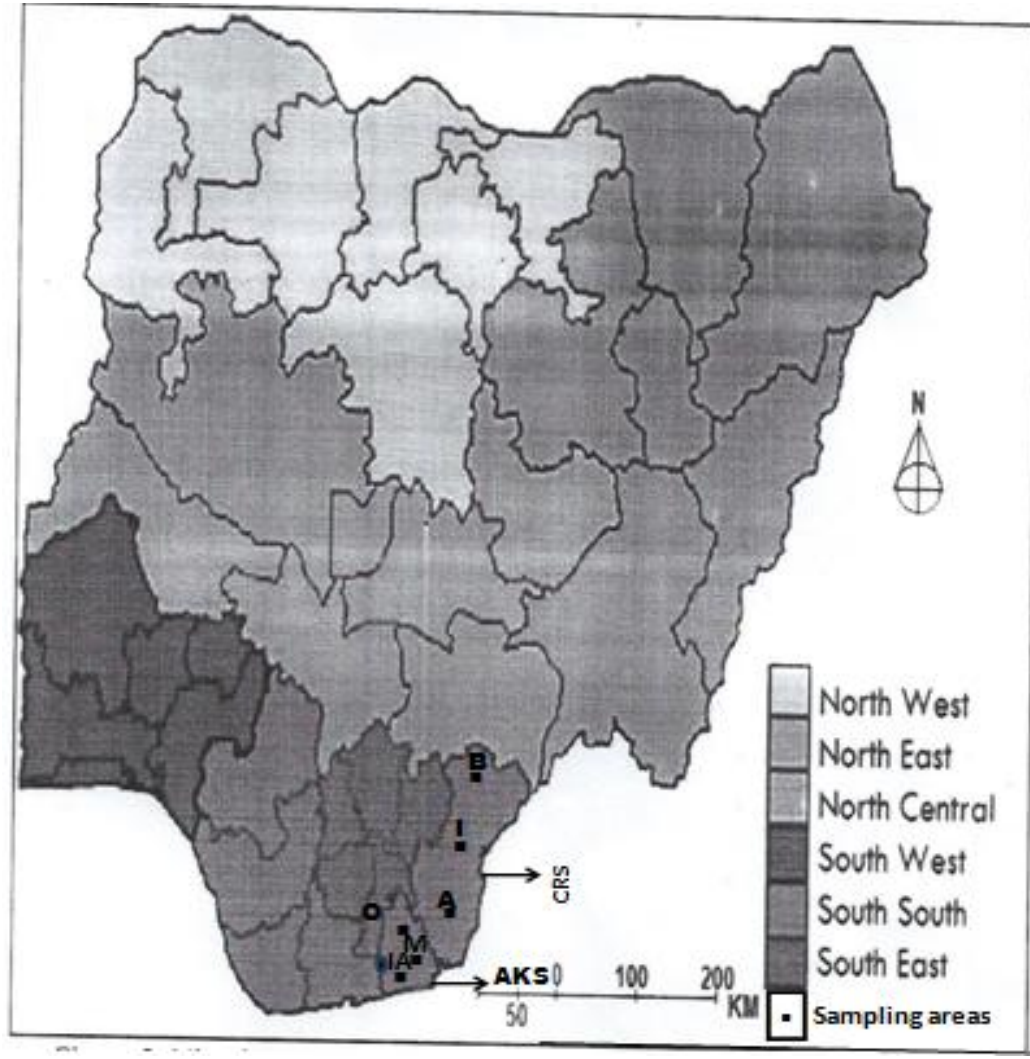

CRS = Cross River State; AKS = AkwaIbom State; B = Bekwarra LGA; I = Ikom;

$\mathrm{A}=$ Akamkpa LGA; O = Oron LGA; M = Mbo LGA; IA = IkotAbasi LGA 
In Table 2 which shows the sanitation coverage of the communities, only $58.10 \%$ and $31.43 \%$ of rural communities in Cross River and Akwalbom States, respectively, have access to improved sanitation facilities, while $41.90 \%$ and $68.57 \%$ respectively, only have access to unimproved sanitation facilities. However, it has been reported that only 39\% Nigerians use improved toilets not shared by more than one household while only $37 \%$ of health facilities in the country have at least one usable toilet (NewsBank, 2018). Further, people who have no sanitation facilities are forced to defecate in the open (NewsBank, 2018). This is in line with the finding of this study. Moreover, there is an absence of sanitation facilities in most of the coastal communities of the Niger Delta region and direct defecation into the surface water has become a traditional practice, coupled with issues of lack of privacy (Cookey et al., 2008).

In this study, there was a high significant difference $(p<0.01)$ between Cross River and Akwalbom States with respect to availability of sanitation facilities, and by implication, the states are associated with open defecation prevalence. This might arise from several factors such as geographical factors. For instance, Abubakar (2018) rates North-Central Nigeria highest $(8.8 \%)$ in terms of open defecation prevalence than South-South $(4.3 \%)$, where the study areas are located. Thus, Abubakar (2018) attributed the difference to the savannah nature of NorthCentral unlike the forest nature of South-south Nigeria. Other factors include rural sanitation behaviours such as availability of functioning latrines, sanitation products and services, social norms around open defecation, perceptions of latrine affordability, selfefficacy to build latrines, etc. (O'Connell, 2014). Other factors relating to the differences between the two states may be associated with remoteness and demographic factors (Cross
River State Bureau of Statistics, 2006; Abubakar, 2018).

Open defecation appears to exist in both Cross River and Akwalbom States of the Niger Delta, as indicated by the observed sanitation facilities in the sampling areas of the two states. The rural coastal communities which are more southerly than those of Cross River state, have a cultural preference for open defecation into surface water, and therefore more prone to open defecation than the upland regions of Cross River State.

\section{References}

Abubakar, I. R., 2018. Exploring the determinants of open defecation in Nigeria using demographic and health survey data. Sc. Total Environ. 637-638, 1456-1465.

Coffey, D., Gupta, A., Hathi, P., Khurana, N., Spears, D., Srivastav, N., Vyas, S., 2014.Revealed preference for open defecation evidence from a new survey in rural North India. Special Article, xiix(38), 43-55.

Cookey, P., Kokpan, B. A., Aguo, M. R., Wenes, W., John, P. C., 2008. $33^{\text {rd }}$ WEDC International Conference 383 388.

Cross River State Bureau of Statistics, 2006. Cross River State Demographic Dividend Profile.

Desai, R., McFarlane, C. and Graham, S., 2015. The politics of open defecation: Informality, body and infrastructure in Mumbai. Antipode, 47(1), 98-120.

Directorate of Statistics, 2013.Statistical Year Book of Akwalbom State of Nigeria. Ministry of Economic Development, AkwaIbom State.

Eja, M. E., 2003. Bacterial indicators of faecal pollution of water supplies and public health: A review. Global J. Med. Sc., 2(2), 81-90.

Eja, M. E., 2006. Socioeconomic indicators and the survival of the tropical rainforest of 
Cross River State of Nigeria. Environmentalist, 26, 83-94.

Lutz, W., 1982. Sampling: How to select people, households, places to study community health. $\quad 3^{\text {rd }}$ ed. International Epidemiological Association: Edinburgh.

NewsBank Inc., 2018. Nigeria needs N959 billion to eradicate open defecation. allAfrica.com - September 17, 2018.

NewsBank Inc., 2019. Addressing open defecation in Nigeria. This Day (Nigeria) - July 18, 2019.

NPC, 2007. The 2006 National Population Census Results: Legal Notice on the Details of the Breakdown of the National and State Provisional Total. NPC, Lagos, Nigeria.FGP, $71 / 52007 / 2500$.

O'Connell, K., 2014. What influences open defecation and latrine ownership in rural households?: Findings from a global review. World Bank Group, 1-28.

O'Reilly, K., Dhanju, R. and Goel, A., 2017. Exploring "The Remote" and "The rural": Open defecation and latrine use in Uttarakhand, India. World
Development, 93, 193-205.

Okon, A. J., 2017. A study of assess, quality of drinking water and sanitation coverage in rural upland and coastal communities of Akwalbom State, Nigeria. A Ph.D thesis, University of Calabar, Calabar.

Okon, A. J., Eja, M. E. \&Kalu, R. E., 2017. A study of access to sanitation profiles of rural upland and coastal communities of AkwaIbom State, Nigeria. Global J. Pure and Appl. Sc. 23, 207-212.

Saleem, M., Burdett, T. and Heaslip, V., 2019. Health and social impacts of open defecation on women: A systematic review. MBG Pub. Health. 19, 158-169.

UNICEF/WHO, 2015. Progress on sanitation and drinking water - 2015 update and MDG Assessment. World Health Organization, Geneva.

UNICEF/WHO, 2017. Progress on drinking water, sanitation and hygiene: 2017 update and SDG Baselines. World Health Organization, Geneva.

WHO and UNICEF, 2014. UNICEF Joint Monitoring Programme Database. http//www.wssinfo.org.

\section{How to cite this article:}

RandymayEja Kalu, KimbolineDonatus Etim, OkonAniekanabasi Jonathan and Matthew Egbobor Eja. 2019. Open Defecation Profile of Rural Communities in Cross River and Akwa Ibom States of the Niger Delta, Nigeria. Int.J.Curr.Microbiol.App.Sci. 8(12): 2332-2340. doi: https://doi.org/10.20546/ijcmas.2019.812.275 